Available online at GSC Online Press Directory

GSC Biological and Pharmaceutical Sciences

e-ISSN: 2581-3250, CODEN (USA): GBPSC2

Journal homepage: https://www.gsconlinepress.com/journals/gscbps

(RESEARCH ARTICLE)

\title{
Larvicidal effect of S-hydroprene and leaf extracts of Azadirachta indica (A. Juss, 1830) on metamorphosis of Culex quinquefasciastus (Say, 1823)
}

Agada Jeremiah ${ }^{1}$, Ogundeko Timothy Olugbenga ${ }^{2,}{ }^{*}$, Mbah Christian Emeka ${ }^{1}$, Bakam Clement Kure ${ }^{3}$, Sow Gudzan John ${ }^{1}$, Bassi Amos Paul ${ }^{4}$ and Ramyil Mamzhi -Crown Seljul ${ }^{5}$

1 Department of Zoology, Faculty of Life Sciences, Ahmadu Bello University, Zaria, Nigeria.

${ }^{2}$ Department of Pharmacology and Therapeutics, College of Medicine and Health Sciences, Bingham University, Jos Campus, Nigeria..

${ }^{3}$ Immunization Coordination Center, Kaduna State Primary Healthcare Development Agency. State Emergency Routine,

Kaduna, Nigeria.

${ }^{4}$ Department of Community Medicine \& Primary Health Care, College of Medicine and Health

Sciences, Bingham University, Jos Campus, Nigeria

${ }^{5}$ Department of Medical Microbiology and Parasitology, College of Medicine and Health Sciences, Bingham University, Jos Campus, Nigeria

Publication history: Received on 08 May 2020; revised on 23 May 2020; accepted on 24 May 2020

Article DOI: https://doi.org/10.30574/gscbps.2020.11.2.0135

\begin{abstract}
Insect Growth Regulators (IGRs) are yet to be explored with the huge Nigerian plant biodiversity despite the biospecificity and environmental friendly characteristics when compared to conventional chemicals. Safer, cheaper and reachable alternatives to the more popular insecticides that are hazardous to human health and the environment have become imperative. The study was designed to evaluate the effect of S-Hydroprene and various solvent leave extracts of Azadirachta indica on the metamorphosis of Culex quinquefasciastus mosquitoes. Methanol, N-Hexane, Chloroform, Aqueous leave extracts of Azadirachta indica and S-Hydroprene were tested on $1^{\text {stand }} 3^{\text {rdthird }}$ instar larvae of $C x$. Quinquefasciastus under laboratory conditions for a consistent period of 6 - 15 days in which growth inhibition was monitored using the control to determine the rate of change for the concentrations $10 \mathrm{mg} / \mathrm{L}, 20 \mathrm{mg} / \mathrm{L}, 30 \mathrm{mg} / \mathrm{L}, 40$ $\mathrm{mg} / \mathrm{L}, 50 \mathrm{mg} / \mathrm{L}$ and $60 \mathrm{mg} / \mathrm{L}$. S-Hydroprene had more deleterious effect on Cx. quinquefasciatus third instar larvae at 60 $\mathrm{mg} / \mathrm{L} 2.8(9 \%)$ when compared with methanolic extract. N-Hexane extract killed more larvae at $60 \mathrm{mg} / \mathrm{L} \mathrm{11.2(37 \% ).}$ Since extracts of $A z$. indica had less toxic effect, they allowed for the survival of $C x$. Quinquefasciastus but extended the larval stages and prevented ecdysis. The first instar larval stage was maintained for sixteen (16) days which is at variance with the regular three to four days larval existence. Leave extracts of Az. Indica and S-Hydroprene at concentration of $10 \mathrm{mg} / \mathrm{L}$ to $60 \mathrm{mg} / \mathrm{L}$ caused morphological deformations of the metamorphosis of Culex quinquefasciastus. The leaf extracts of $A z$. indica possess explorable larvicidal properties for control of larva and adult mosquitoes.
\end{abstract}

Keywords: Azadirachta Indica; Culex quinquefasciastus; Insect Growth Regulators; Larvicidal; Morphology; SHydroprene.

\section{Introduction}

Insect growth regulators (IGRs) are intrinsically non-toxic, biologically specific and environmentally friendly compared to other conventional chemical insecticides and larvicides [1]. Among these IGRs, Methoprene has been reported to be effective against some mosquito vector species [2]. Insect resistance to some IGRs other than Hydroprene may be due

\footnotetext{
* Corresponding author: Ogundeko Timothy Olugbenga
} 
to either degradation of the artificially applied IGRs in the insect's body before reaching their target sites or the modification of the target sites resulting in reduced affinity of juvenile hormone binding proteins (JHBPs) to the juvenile hormone analogues (JHAs) [3].Among all the species of mosquitoes known, Culex quinquefasciastus are the most widespread[4].Culex quinquefasciastus are vectors of certain diseases and disease causing agents such as Ross River Virus, Alfuy, Almpiwar, Corriparta, Dengue, Sindbis and Japanese Encephalitis Virus [5, 6]. It is also the main vector of the filarial parasite Wuchereria bancrofti which causes the human lymphatic filariasis that lead to acute and chronic morbidity, affecting people of all ages and sexes throughout the tropical and sub-tropical areas of the world [7, 8]. Azadirachta indica A. juss (AI; Family: Meliaceae) is a popular medicinal plant originally grown in India [9] but is now being cultivated in almost every part of the world including Nigeria $[10,11]$ where it is popularly called "Dogonyaro". It is one of the most useful medicinal plants [12]. It is a large evergreen tree growing 10-11 m tall. The leaves are divided into numerous leaflets each resembling a full-grown leaf [13]. Every part of neem (Azadirachta indica) has been advocated to have medicinal properties [14]. Extracts from the plant offers a promising larvicidal against Culex quinquefasciastus and other species of mosquitoes, including growth inhibition, abnormal development, elongation of larval period and sometimes no pupation [15]. To evaluate the effects of extract of Azadirachta indica on Culex quinquefasciastus larvae.

\section{Material and methods}

\subsection{Study Area}

Study was carried out in Ahmadu Bello University, Zaria, Nigeria (Figure 1). It lies between latitude $11^{\circ} 15^{\prime} \mathrm{N}$ to $11^{\circ} 3^{\prime} \mathrm{N}$ and longitude $7^{\circ} 30^{\prime} \mathrm{E}$ to $7^{\circ} 45^{\prime} \mathrm{E}$. The area is characterized by a grassland ecosystem with trees being widely spaced so that the canopy does not close. The annual rainfall ranges between $1016 \mathrm{~mm}$ and $1524 \mathrm{~mm}$ with a relative humidity ranging between $60 \%$ to $80 \%$ [16].

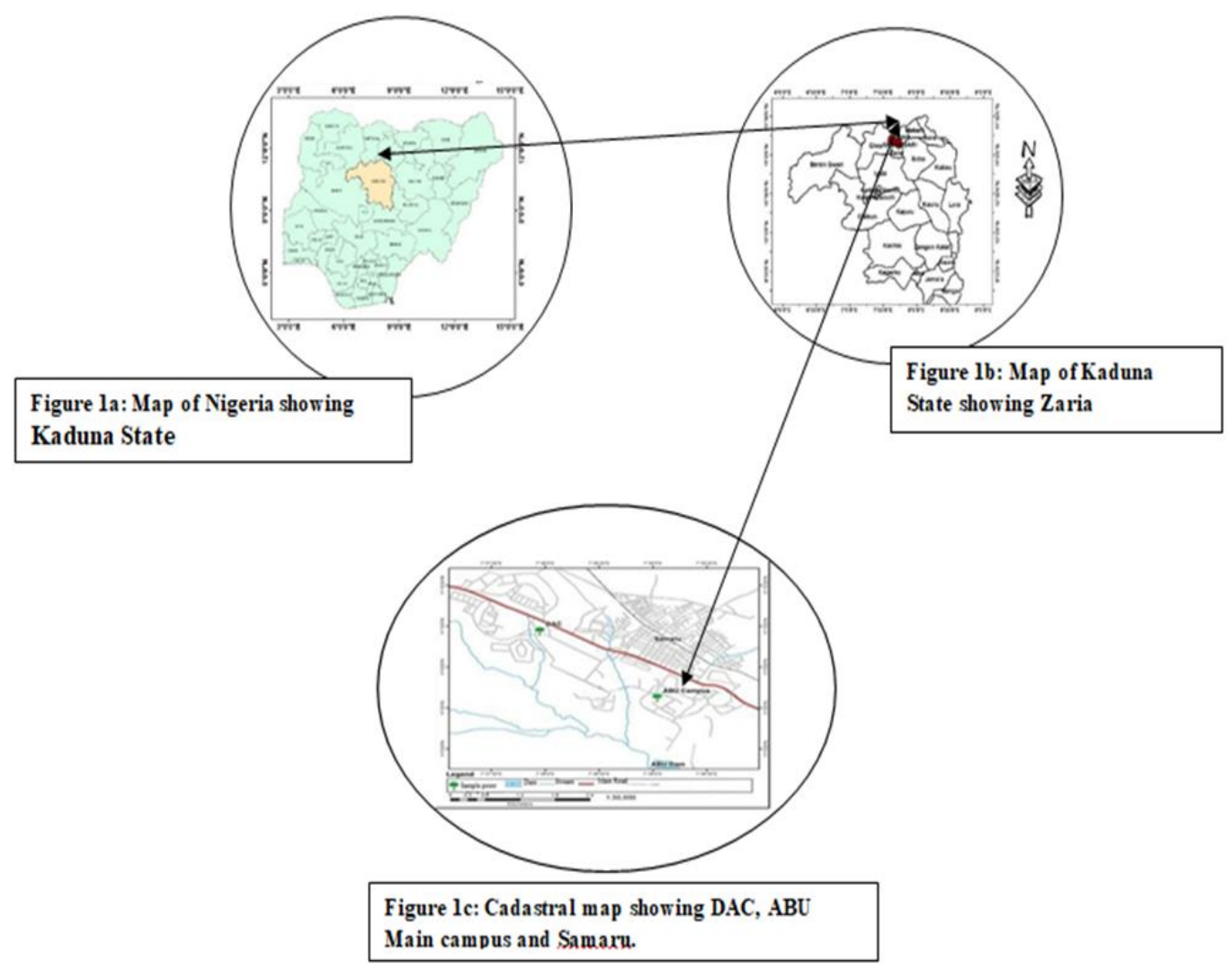

Figure 1 Cadastral map showing Nigeria, Kaduna State and Samaru campus 


\subsection{Collection and Identification of Plant material}

Fresh leaves of Azadirachta indica were collected from the premises Ahmadu Bello University, Zaria and identified at the herbarium of the Department of Botany (voucher number 90104). The leaves were air-dried under the shade and pulverized using mortar and pestle.

\subsection{Solvent Extraction of Azadirachta indica and Preparation of Stock Solutions}

The plant material was extracted by weighing $500 \mathrm{~g}$ powder of Azadirachta indica each into four different glass containers with $1000 \mathrm{ml}$ of methanol, distilled water, chloroform and $\mathrm{N}$-Hexane respectively and allowed for 72 hours. The contents were filtered using muslin and cotton wool respectively and evaporated via the water bath at $60{ }^{\circ} \mathrm{C}-65$ ${ }^{\circ} \mathrm{C}$.

Stock solution of the IGR was prepared by dissolving $250 \mathrm{mg}$ of S-Hydroprene in $2 \mathrm{ml}$ of dimethylsulphoxide (DMSO) to obtain a homogenous solution that is miscible with water. Twenty five milliliters of water was then added to obtain the stock. Same was carried out for the other solvent extracts without DMSO dilution as a result of its solubility in water according to [20]. Serial dilution for the stock solution was made afterwards.

\subsection{Collection of Adult Mosquitoes and Breeding of Larvae and Identification of Adult Mosquitoes}

Twenty 20 blood-fed adult female Culex quinquefasciastus were collected by trapping them with the use of a test tube while resting on the walls of some rooms in the students' hostel in ABU main campus, transferred via entomological cages, identified by an entomologist and bred according to [21, 22] Preserved female adult mosquitoes were observed under a microscope and identified by the use of published keys according to [8].

\subsection{Bioassay of Mosquito Larva Using S-Hydroprene and Leaf Extracts of Azadirachta indica}

The established colonies maintained at optimum conditions of $25-27^{\circ} \mathrm{C}$ and $70-80 \%$ relative humidity in the Laboratory of Department of Zoological Sciences, ABU Zaria. The physicochemical parameters of the water - $\mathrm{pH}$ and dissolved oxygen were checked for breeding quality. The larvae of the mosquitoes were fed with grinded digestive biscuit throughout the experimental process continues until they to emerged as adult.

S-Hydroprene and the leaf extracts of Azadirachta indica were investigated based on concentration. Larval development and larvicidal efficacy were screened against the larval instars of Culex quinquefasciatus. For screening of larvicidal activity, the first larval instars of Culex quinquefasciastus were separated into a batch of thirty (30) and was transferred into separate petri dish containing $100 \mathrm{ml}$ of distilled water. This was again replicated into 5 . The Same replication was made in the case of the control set-up but devoid of the neem extracts according to [20]. The whole setup was allowed for a consistent period of 6 - 15 days in which growth inhibition was monitored using the control to determine the rate of change for the concentrations $10 \mathrm{mg} / \mathrm{L}, 20 \mathrm{mg} / \mathrm{L}, 30 \mathrm{mg} / \mathrm{L}, 40 \mathrm{mg} / \mathrm{L}, 50 \mathrm{mg} / \mathrm{L}$ and $60 \mathrm{mg} / \mathrm{L}$.

The number of dead larvae of Culex quinquefasciastus and Aedes aegypti in the various test concentrations used were subjected to probit analysis. Control mortality was corrected using Abbott's formula, $\mathrm{P}=\frac{P o-P c}{100-P c} \times 100(\mathrm{P}=\mathrm{Abbott}$ 's corrected mortality, Po = percentage of observed mortality, Pc = percentage of control mortality) [20].

\subsection{Statistical Analysis}

Analysis of variance (ANOVA) was used to test for significant differences in larval mortality amongst the various concentrations of solvent- based extracts. Duncan's multiple range tests was employed in separating differing means. Student's T - Test was used to compare the efficacy of the extracts of Azadirachta indica and S-Hydroprene on the mosquito species. Values were considered statistically significant at $\mathrm{P} \leq 0.05$.

\section{Results and discussion}

Larval mortality of the third instar of Culex quinquefasciastus increased as the concentration from $10 \mathrm{mg} / \mathrm{L} \mathrm{to} 60 \mathrm{mg} / \mathrm{L}$ for all extracts of Azadirachta indica increased using different media. 
That of S-Hydroprene exhibited similar pattern with the methanol. The results obtained with $\mathrm{N}$-Hexane extract showed significantly $(0.000 \mathrm{P} \leq 0.05)$-Table1.

Table 1 Effect of extracts of A. indica and S-Hydroprene on mortality of third instar larvae of Culex quinquefasciastus after 24 hours

\begin{tabular}{lllllll}
\hline $\begin{array}{l}\text { Conc. } \\
(\mathbf{m g} / \mathrm{L})\end{array}$ & $\begin{array}{l}\text { No. } \\
\mathbf{p e r} \\
\mathbf{E x} \\
\mathbf{p} .\end{array}$ & $\begin{array}{l}\text { N-Hexane } \\
\text { Extract } \\
\text { Mean } \\
\text { Mortality } \pm \mathbf{S E}\end{array}$ & $\begin{array}{l}\text { Aqueous Extract } \\
\text { Mean } \\
\text { Mortality } \pm \mathbf{S E}\end{array}$ & $\begin{array}{l}\text { Chloroform } \\
\text { Extract } \\
\text { Mean } \\
\text { Mortality } \pm \text { SE }\end{array}$ & $\begin{array}{l}\text { Methanol Extract } \\
\text { Mean } \\
\text { Mortality } \pm \text { SE }\end{array}$ & $\begin{array}{l}\text { S-Hydroprene } \\
\text { Mean } \\
\text { Mortality } \pm \text { SE }\end{array}$ \\
\hline Control & 30 & $1.0 \pm 0.32(3)$ & $1.0 \pm 0.32(3)$ & $1.0 \pm 0.32(3)$ & $1.0 \pm 0.32(3)$ & $1.0 \pm 0.32(3)$ \\
10 & 30 & $3.8 \pm 0.55(13)^{\mathrm{d}}$ & $5.4 \pm 0.54(18)^{\mathrm{b}}$ & $3.6 \pm 0.75(15)^{\mathrm{b}}$ & $1.4 \pm 0.58(5)^{\mathrm{a}}$ & $1.4 \pm 0.51(5)^{\mathrm{ab}}$ \\
20 & 30 & $5.4 \pm 0.75(18)^{\mathrm{cd}}$ & $5.2 \pm 0.02(17)^{\mathrm{b}}$ & $4.4 \pm 0.03(15)^{\mathrm{b}}$ & $2.2 \pm 0.66(7)^{\mathrm{a}}$ & $1.4 \pm 0.60(5)^{\mathrm{ab}}$ \\
30 & 30 & $6.8 \pm 0.97(23)^{\mathrm{bc}}$ & $5.8 \pm 0.86(19)^{\mathrm{b}}$ & $6.6 \pm 0.87(22)^{\mathrm{a}}$ & $2.6 \pm 0.87(9)^{\mathrm{a}}$ & $2.0 \pm 0.51(7)^{\mathrm{ab}}$ \\
40 & 30 & $8.6 \pm 0.75(29)^{\mathrm{ab}}$ & $7.4 \pm 0.08(25)^{\mathrm{ab}}$ & $7.0 \pm 0.32(23)^{\mathrm{a}}$ & $2.0 \pm 0.75(7)^{\mathrm{a}}$ & $1.4 \pm 0.37(5)^{\mathrm{c}}$ \\
50 & 30 & $9.0 \pm 0.25(30)^{\mathrm{a}} \mathrm{b}$ & $7.8 \pm 0.86(26)^{\mathrm{ab}}$ & $7.8 \pm 0.86(26)^{\mathrm{a}}$ & $3.2 \pm 0.15(7)^{\mathrm{a}}$ & $2.2 \pm 0.25(7)^{\mathrm{ab}}$ \\
LC50 $^{\mathrm{a}}$ & & 1.216 & 1.172 & 1.211 & 1.059 & 1.047 \\
F-Value & & 14.453 & 8.095 & 10.956 & 1.212 & 1.674 \\
P-Value & & 0.000 & 0.000 & 0.000 & 0.330 & 0.164 \\
\hline
\end{tabular}

Key: SE $=$ Stan dard Error, Conc. = Concentration, No = Number. Figures in parenthesis are in percentages.

Superscripts with different letters are significantly different at $\mathrm{p} \leq 0.0$

Approximately 9 (30\%) of the first instar larvae of $C x$. quinquefasciastus survived after sixteen (16) days with in both methanol and aqueous extracts of $A$. indica at $10 \mathrm{mg} / \mathrm{L}$ while only $2(7 \%)$ of the organisms survived within same period of treatment with S-Hydroprene. However, increase in concentration of $A$. indica did not result in a corresponding increase in the number of survival for all solvent used for extraction (Table 2).

Table 2 Effect of the extracts of the leaf of Az. indica and S-Hydroprene on the survival of first instar larvae of Culex quinquefasciastus

\begin{tabular}{|c|c|c|c|c|c|}
\hline $\begin{array}{l}\text { Conc. } \\
\text { (mg/L) }\end{array}$ & $\begin{array}{l}\text { N-Hexane } \\
\text { extract } \\
\text { Mean } \\
\text { Survival } \pm \text { SE }\end{array}$ & $\begin{array}{l}\text { Aqueous extract } \\
\text { Mean } \\
\text { Survival } \pm \text { SE }\end{array}$ & $\begin{array}{l}\text { Chloroform } \\
\text { extract } \\
\text { Mean } \\
\text { Survival } \pm \text { SE }\end{array}$ & $\begin{array}{l}\text { Methanol } \\
\text { extract } \\
\text { Mean } \\
\text { Survival } \pm \text { SE }\end{array}$ & $\begin{array}{l}\text { S-Hydroprene } \\
\text { Mean } \\
\text { Survival } \pm \text { SE }\end{array}$ \\
\hline Control & $24.00 \pm 0.63(80)^{\mathrm{a}}$ & $24.00 \pm 0.63(80)^{\mathrm{a}}$ & $24.00 \pm 0.63(80)^{a}$ & $24.00 \pm 0.63(80)^{\mathrm{a}}$ & $24.00 \pm 0.63(80)^{a}$ \\
\hline 10 & $2.40 \pm 0.51(8)^{\mathrm{b}}$ & $8.80 \pm 0.14(29)^{\mathrm{bc}}$ & $1.20 \pm 0.58(4)^{\mathrm{b}}$ & $9.00 \pm 0.00(30)^{\mathrm{b}}$ & $2.00 \pm 0.55(7)^{\mathrm{b}}$ \\
\hline 20 & $2.20 \pm 0.49(7)^{\mathrm{b}}$ & $9.20 \pm 0.58(31)^{b}$ & $0.60 \pm 0.40(2)^{b}$ & $6.60 \pm 0.40(22)^{c}$ & $1.60 \pm 0.40(5)^{\mathrm{b}}$ \\
\hline 30 & $1.60 \pm 0.25(5)^{\mathrm{b}}$ & $8.20 \pm 0.49(27)^{\mathrm{bc}}$ & $0.60 \pm 0.40(2)^{\mathrm{b}}$ & $6.40 \pm 0.68(21)^{c}$ & $1.40 \pm 0.60(5)^{\mathrm{b}}$ \\
\hline 40 & $1.80 \pm 0.20(6)^{\mathrm{b}}$ & $7.80 \pm 0.49(26)^{b c}$ & $0.40 \pm 0.40(1)^{\mathrm{b}}$ & $5.20 \pm 0.02(17)^{c}$ & $2.00 \pm 0.05(7)^{\mathrm{b}}$ \\
\hline 50 & $2.40 \pm 0.51(8)^{\mathrm{b}}$ & $7.00 \pm 0.71(23)^{\mathrm{cd}}$ & $1.80 \pm 0.66(6)^{b}$ & $6.00 \pm 0.70(20)^{c}$ & $1.60 \pm 0.68(5)^{\mathrm{b}}$ \\
\hline 60 & $1.20 \pm 0.20(4)^{\mathrm{b}}$ & $6.60 \pm 0.40(22)^{\mathrm{d}}$ & $0.40 \pm 0.25(1)^{\mathrm{b}}$ & $6.40 \pm 0.98(21)^{c}$ & $1.60 \pm 0.25(5)^{\mathrm{b}}$ \\
\hline F-Value & 375.621 & 84.641 & 313.085 & 88.716 & 175.225 \\
\hline P-Value & 0.000 & 0.000 & 0.000 & 0.000 & 0.000 \\
\hline
\end{tabular}


In the case of S-Hydroprene, the effect was almost the same for all concentrations where approximately one larva survived. The results obtained from methanol and aqueous extracts using various concentrations probably indicates the closeness of the potency of the active ingredients in methanol which is probably less toxic to the first instar larvae but the effect of the chloroform extract. of Az. indica definitely suggests the toxic potency of chloroform in addition to the effect of Az. indica to first instar larvae (Table 2).

$\mathrm{N}$-Hexane and chloroform extracts of Az. Indica treatments on the first instar larvae of Cx. quinquefasciastus survived for fifteen (15) to sixteen (16) days without metamorphosing into pupae in concentrations which range from $10 \mathrm{mg} / \mathrm{L}$ to $60 \mathrm{mg} / \mathrm{L}$ (Table 3).

Table 3 Mosquito larval survival in days following the application of S-Hydroprene and extracts of Az. Indica

\begin{tabular}{|c|c|c|c|c|c|}
\hline $\begin{array}{l}\text { Conc. } \\
\text { (mg/L) }\end{array}$ & $\begin{array}{l}\text { N-Hexane } \\
\text { extract } \\
\text { Mean } \\
\text { Days } \pm \text { SE }\end{array}$ & 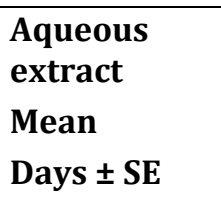 & $\begin{array}{l}\text { Chlorofor } \\
\text { m extract } \\
\text { Mean } \\
\text { Days } \pm \text { SE }\end{array}$ & $\begin{array}{l}\text { Methanol } \\
\text { extract } \\
\text { Mean } \\
\text { Days } \pm \text { SE }\end{array}$ & $\begin{array}{l}\text { S- } \\
\text { Hydroprene } \\
\text { Mean } \\
\text { Days } \pm \text { SE }\end{array}$ \\
\hline Control & $8.00 \pm 0.00$ & $8.00 \pm 0.00$ & $8.00 \pm 0.00$ & $8.00 \pm 0.00$ & $8.00 \pm 0.00$ \\
\hline 10 & $13.80 \pm 0.37^{b}$ & $10.40 \pm 0.58^{\mathrm{bc}}$ & $15.20 \pm 0.20^{\mathrm{a}}$ & $12.40 \pm 0.25^{\mathrm{a}}$ & $12.00 \pm 1.09^{a}$ \\
\hline 20 & $15.60 \pm 0.25^{\mathrm{a}}$ & $11.00 \pm 0.40^{c}$ & $15.40 \pm 0.25^{\mathrm{a}}$ & $12.00 \pm 0.32^{\mathrm{a}}$ & $13.80 \pm 0.74^{\mathrm{a}}$ \\
\hline 30 & $15.80 \pm 0.20^{\mathrm{a}}$ & $11.60 \pm 0.51^{\mathrm{abc}}$ & $15.00 \pm 0.45^{\mathrm{a}}$ & $12.40 \pm 0.25^{\mathrm{a}}$ & $12.80 \pm 1.56^{\mathrm{a}}$ \\
\hline 40 & $15.80 \pm 0.20^{\mathrm{a}}$ & $11.80 \pm 0.58 \mathrm{abc}$ & $15.00 \pm 0.00^{\mathrm{a}}$ & $12.20 \pm 0.20^{\mathrm{a}}$ & $13.60 \pm 0.75^{\mathrm{a}}$ \\
\hline 50 & $15.60 \pm 0.40^{\mathrm{a}}$ & $12.40 \pm 0.45^{\mathrm{ab}}$ & $15.00 \pm 0.00^{\mathrm{a}}$ & $11.80 \pm 0.37^{\mathrm{a}}$ & $12.00 \pm 0.45^{\mathrm{a}}$ \\
\hline 60 & $15.80 \pm 0.6^{\mathrm{a}}$ & $12.60 \pm 0.51^{\mathrm{a}}$ & $14.80 \pm 0.20^{\mathrm{a}}$ & $12.20 \pm 0.37^{\mathrm{a}}$ & $12.80 \pm 0.74^{\mathrm{a}}$ \\
\hline F-Value & 67.048 & 12.181 & 147.608 & 32.741 & 6.110 \\
\hline P-Value & 0.000 & 0.000 & 0.000 & 0.000 & 0.000 \\
\hline
\end{tabular}

Key: SE = Standard Error, Conc. $=$ Concentration, No = Number Superscripts with different letters are significantly different at $\mathrm{p}<0.05$

First instar larvae of $C x$. Quinquefasciastus treated with S- Hydroprene survived from 12 to 14 days across $10 \mathrm{mg} / \mathrm{L}$ to $60 \mathrm{mg} / \mathrm{L}$ ranges of concentration.

The effect of treatment with Leaf extracts of Az. Indica and S-Hydroprene on the morphology of the organisms was in form of abnormalities on the body wall and chitinous exoskeleton (Figures 2, 3 and 4). These effects were not observed in the control group (Figure 5).

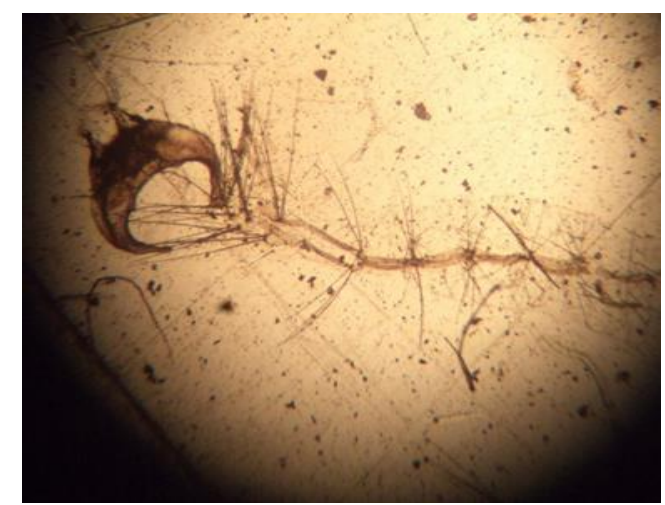

Figure 2 Decomposition Head and Abdomen of C. quinquefasciastus

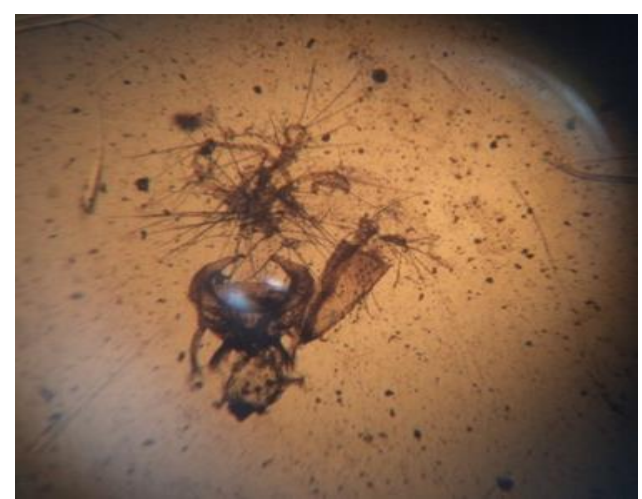

Figure 3 Decomposing body parts of C. quinquefasciastus 


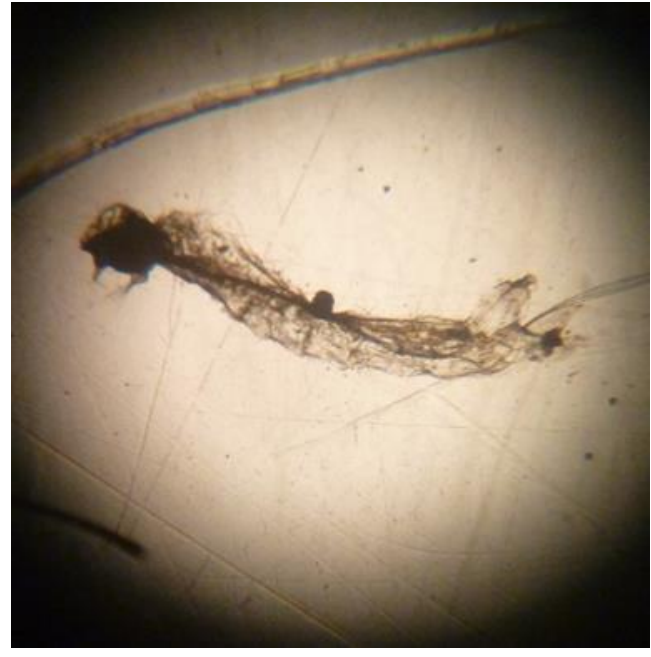

Figure 4 Larva-pupa intermediate of

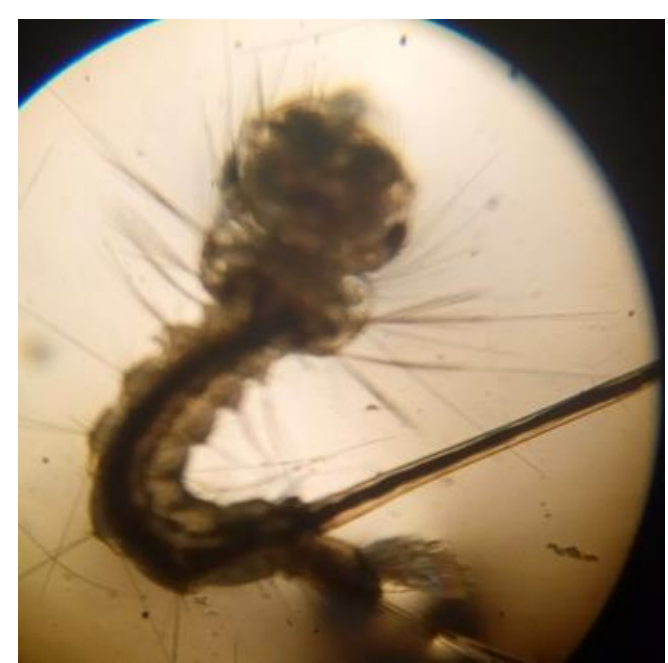

Figure 5 Control

Culex quinquefasciastus

Figure 2 - 5: Morphological effect of Azadirachta indica (10 mg/L to $60 \mathrm{mg} / \mathrm{L}$ ) and S-Hydroprene (10 mg/L to $60 \mathrm{mg} / \mathrm{L}$ ) on experimental and control groups of first instar larvae of Culex quinquefasciastus

All extracts of Az. Indica produced varying degrees of mortality on the test larvae. N-Hexane extract was observed to kill more mosquito larvae than the other extracts of Az. indica and S-Hydroprene at same concentration. It also however killed more mosquito larvae than S-Hydroprene at the same concentration. This is probably because N-Hexane solvent extracted more active ingredients from Az. indica than the other solvents. This is similar to the work of [23] that used methanol extract of Az. indica against third and fourth instar larvae of C. quinquefasciastus in India and obtained total kill of the test specimen. The observed effect of $\mathrm{N}$-Hexane extract of neem on larvae of C. quinquefasciastus is probably because of the failure of larvae to metamorphose into the pupae stage due to the inhibition of chitin formation or due to their inability to shed their exo-cuticle and inadequate intake of air to split the old cuticle. This concurs with the observation made by [24], [25]

\section{Conclusion}

Both leave extracts of $A z$. Indica and S-Hydroprene at concentration of $10 \mathrm{mg} / \mathrm{L}$ to $60 \mathrm{mg} / \mathrm{L}$ caused morphological deformations of larval-pupal intermediate and damage of head and body on Culex quinquefasciastus. N-Hexane extract gave the highest effect with mortality rate of $37 \%(60 \mathrm{mg} / \mathrm{L}$ ). Furthermore, S-Hydroprene and the leaf extracts of $\mathrm{Az}$. indica possess explorable larvicidal properties for control of larva and adult mosquitoes. This may open another vista to compare the current larvicides and this often mention third generation larvicides.

\section{Compliance with ethical standards}

\section{Acknowledgments}

Many thanks to Prof I.S Ndams, Mr D.A Adebote and Laboratory Technologists in the Pharmacognosy, Dispensing and Biochemistry Laboratories - Ahmadu Bello University Zaria.

\section{Disclosure of conflict of interest}

Authors hereby declare no conflict of interest. 


\section{References}

[1] Siva K, Kadarkarai M and Balamurugan C. (2015). Insect growth regulatory activity of Acalypha alnifolia (Euphorbiaceae) and Vitex negundo (Verbenaceae) leaf extracts against Aedes aegypti (Diptera: Culicidae). International Journal of Mosquito Research, 2 (1), 47-52.

[2] Cornel AJ, Stanich MA, Farley D, Mulligan FS and Byde G. (2000). Methoprene tolerance in Aedes nigromaculis in Fresono Country, California. Journal of American Mosquito Control Association, 16, 223-8.

[3] Suman DS, Yi W, Anwar LB and Randy G. (2013). Ovicidal activity of three insect growth regulators against Aedes and Culex mosquitoes. Elsevier, 128, 103- 109.

[4] Weinstein P, Laird M and Browne G. (1997). Exotic and endemic mosquitoes in New Zealand as potential arbovirus vectors. Wellington, Ministry of Health.

[5] De Almeida AB and Freedman DO. (1999). Epidemiology and immunopathology of bancroftian filariasis. Microbes and infection, 1, 1015-1022.

[6] Parthasarathi A, Chettiar K, Rajan M and Savarimuthu I. (2016). Evaluation of Larval Toxicity of Lantana Camara L. and Catharanthus Roseus L. against Culex Quinquefasciatus say and Aedes Aegypti L. Entomology, Ornithology and Herpetology, 5, 1-5.

[7] Hettiaratchi UPK, Munasingha DHN, Chandrasekharan NV, Karunanayake EH and Jayasekera NA. (2000). Polymerase chain reaction based method for the detection of Culex quinquefasciatus (Diptera: Culicidae). Bulletin of Entomological Research, 90, 63-68.

[8] Service M. (Ed.). (2012). Medical Entomology for Students.Cambridge University Press, 1-30.

[9] Ofem OE, Ikpi DE and Essien NM. (2013). Increased bile flow rate and altered composition of bile induced by ethanolic leaf extract of Azadirachta indica (neem) in rats. Niger J Exp Clin Biosci, 1, 18-22.

[10] Das BK, Mukherjee SC and Murjani O. (2003). Acute toxicity of neem (AI) in Indian carps. J Aquac Trop, 17, 2333.

[11] Sonibare MO, Isiaka AO, Taruka WM, Williams NS, Soladoye M and Emmanuel O. (2006). Constituents of neem leaves. Nat Prod Commu, 23-6.

[12] Kausik BI and Ranajet KB. (2002). Biological activities and medicinal properties of neem plant. Curr Sci, 82, 133645.

[13] Koul O, Isman MB and Ketkar CM. (1990). Properties and uses of neem, Azadirachta indica. Can J Bot, 68, 1-11.

[14] Rashid M and Ahmad A. (2013). The Effect of Neem (Azadirachta Indica) Leaves Extract on the Ecdysis and Mortality of Immature Stages of Common House Mosquito Culex Pipiens Fatigans. Biologia (Pakistan), 59 (2), 213-19.

[15] Deepalakshmi S and Jeyabalan D. (2017). Studies on Mosquitocidal and biological activity of endemic plants of Nilgiris Hills against filarial vector, Culex quinquefasciatus (Say) (Insecta: Diptera: Culicidae). International Journal of Advanced Research in Biological Sciences, 4(3), 137-151.

[16] Micheal C. (2014). Populations and Plasmodiumfalciparum Infection of Anopheles sp in Settlements around the ZariaDam, Zaria, Kaduna State.Unpublished M.Sc. Thesis. Department of Biological Sciences, Faculty of Science, Ahmadu Bello University, Zaria, Nigeria, 1-17.

[17] Geospatial Analysis Mapping and Environmental Research Solutions. (2018). Map of Kaduna State Nigeria showing Local Government Area of Kaduna State.

[18] Department of Geography. (2018). Cadastral map showing DAC, ABU Main campus and Samaru. Faculty of Physical Science, Ahmadu Bello University, Zaria.

[19] Adebote DA and Adeyemi H. (2011). Larvicidal Efficacy of Solvent-Extrcted Stem Bark of Bobgunnia madagascariensis (Desv.) J . H . Kirkbr and Wiersema (Caesalpiniaceae) against Culex quinquefasciatus. Journal of Applied Environmental and Biological Science, 1 (7), 101-6. 
[20] Suzuki Y, Barik TK, Johnson RM and Rasgon JL. (2015). In vitro and in vivo host range of Anophelesgambiae densovirus (AgDNV). ScientificReports, 5, 12-70.

[21] Barik TK, Yasutsugu S and Jason LR. (2016). Factors Influencing Infection and Transmission of Anopheles Gambiae Densovirus (AgDNV) in Mosquitoes. Peer Journal.

[22] Chakkaravarthy VM, Ambrose T, Vincent S, Arunachalam R, Paulraj MG, Ignacimuthu S and Annadurai G. (2011). Bioefficacy of Azadirachta indica (A. Juss) and Datura metel (Linn.) Leaves Extracts in Controlling Culex quinquefasciatus (Diptera: Culicidae). Journal of Entomology, 8, 191-197.

[23] Linton YM, Nisbet AJ and Mordue AJ. (1997). The effects of azadirachtin on the testes of the desert locust Sch. gregaria. Journal of Insect Physiology, 43, 1077- 1084.

[24] Adel MM. (2012). Lufenuron impairs the chitin synthesis and development of Spodoptera littoralis Bosid. (Lepidoptera: Noctuidae). Journal of Applied Science Resources, 8 (5), 27-66.

[25] Zorzetti J, Constanski K, Santoro PH, Fonseca ICB and Neves PMOJ. (2015). Growth regulator insecticides for the control of the lesser mealworm beetle Alphitobius diaperinus (Coleoptera: Tenebrionidae). Revista Colombiana de Entomología, 41 (1), 24-32.

\section{How to cite this article}

Agada J, Ogundeko TO, Mbah CE, Bakam CK, Sow GJ, Bassi AP and Ramyil MS. (2020). Larvicidal effect of S-Hydroprene and leaf extracts of Azadirachta indica (A. Juss, 1830) on metamorphosis of Culex quinquefasciastus (Say, 1823). GSC Biological and Pharmaceutical Sciences, 11(2), 242-249. 